Received: 9 August 2018

Accepted: 15 May 2019

Published online: 30 May 2019

ENTIFIC REPRTS

\title{
Contrasting methane emissions from upstream and downstream rivers and their associated subtropical reservoir in eastern China
}

LeYang

Subtropical reservoirs are an important source of atmospheric methane $\left(\mathrm{CH}_{4}\right)$. This study investigated the spatiotemporal variability of bubble and diffusive $\mathrm{CH}_{4}$ emissions from a subtropical reservoir, including its upstream and downstream rivers, in eastern China. There was no obvious seasonal variation in $\mathrm{CH}_{4}$ emissions from the main reservoir, which increased slightly from the first half year to the next half year. In the upstream river, $\mathrm{CH}_{4}$ emissions were low from February to June and fluctuated widely from July to January due to bubble activity. In the downstream river, $\mathrm{CH}_{4}$ emissions were lowest in February, which was possibly influenced by the low streamflow rate from the reservoir (275 $\mathrm{m}^{3} \mathrm{~s}^{-1}$ ) and a short period of mixing. There was spatial variability in $\mathrm{CH}_{4}$ emissions, where fluxes were highest from the upstream river $\left(3.65 \pm 3.24 \mathrm{mg} \mathrm{CH}_{4} \mathrm{~m}^{-2} \mathrm{~h}^{-1}\right)$ and lowest from the main reservoir $\left(0.082 \pm 0.061 \mathrm{mg} \mathrm{CH}_{4} \mathrm{~m}^{-2} \mathrm{~h}^{-1}\right)$, and emissions from the downstream river were $0.49 \pm 0.20 \mathrm{mg} \mathrm{CH}_{4} \mathrm{~m}^{-2}$ $\mathrm{h}^{-1}$. Inflow rivers are hot spots in bubble $\mathrm{CH}_{4}$ emissions that should be examined using field-sampling strategies. This study will improve the accuracy of current and future estimations of $\mathrm{CH}_{4}$ emissions from hydroelectric systems and will help guide mitigation strategies for greenhouse gas emissions.

Hydropower has historically been regarded as a clean energy source, however, the view is challenged by a growing body of research that considers hydroelectric reservoirs to be carbon sources. For example, Deemer et al. (2016) showed that $\mathrm{CH}_{4}$ emissions were responsible for the majority of the radiative forcing from reservoir water surfaces, totalling approximately $80 \%$ over a 100 -year timescale ${ }^{1}$. Greenhouse gas emission data are available for 36 Asian reservoirs, of which $\mathrm{CH}_{4}$ emission flux data have been reported for three reservoirs in China, including Three Gorges ${ }^{2,3}$, Ertan $^{4}$, and Miyun ${ }^{5}$. However, there are more than 98,000 dams of varying sizes and 142 large-size hydroelectric reservoirs in a range of geographical regions and climate zones in China, excluding dams that are either under construction or planned, from which $\mathrm{CH}_{4}$ emission fluxes remain to be assessed.

Diffusive flux and gas bubble flux are the primary pathways for $\mathrm{CH}_{4}$ emissions from open water areas of reservoirs ${ }^{6}$. Ebullition has been shown to be the dominant $\mathrm{CH}_{4}$ emission pathway, albeit episodic ${ }^{7}$, but pulses of gas bubbles often occur during periods of rapidly falling barometric pressure in lakes, reservoirs, and peatland ${ }^{7-10}$. Ebullitive $\mathrm{CH}_{4}$ flux is reported to be 1-3 orders of magnitude greater than diffusive $\mathrm{CH}_{4}$ flux ${ }^{11,12}$, and high ebullitive $\mathrm{CH}_{4}$ flux, observed in shallow water, river deltas, and inflow rivers ${ }^{11-13}$, is shown to be influenced by allochthonous organic carbon input and burial ${ }^{14}$. Chamber methods were used to measure $\mathrm{CH}_{4}$ emission flux from three large reservoirs in China, where the total $\mathrm{CH}_{4}$ emission flux (diffusion + ebullition) was measured across the water-air interface ${ }^{2-5}$; however, it is likely that these studies did not capture the magnitude of bubble $\mathrm{CH}_{4}$ flux.

Subtropical reservoirs are strong atmospheric $\mathrm{CH}_{4}$ sources with strong spatial variability ${ }^{15}$. Such variations are presumably caused by changes in hydrological characteristics from impoundment. For example, increases in the water level, reduced water velocity, and flooded soils near the bank impact $\mathrm{CH}_{4}$ emissions from a new reservoir compared with the original river ${ }^{7,16}$. Similarly, $\mathrm{CH}_{4}$ emission levels from outlets downstream and inflow rivers upstream of reservoirs were distinct from those of the reservoir water ${ }^{7,17,18}$, due to variability in hydrological variables, such as water velocity and depth ${ }^{2}$, and dam operation strategy ${ }^{19}$. Temporal variability in $\mathrm{CH}_{4} \mathrm{emissions}$ has been attributed to changes in temperature, water column mixing, dissolved oxygen (DO) concentration, and other environmental variables, including retention time and benthic metabolism ${ }^{2,20,21}$. For example, $\mathrm{CH}_{4}$

Zhejiang Academy of Forestry, Hangzhou, 310023, China. Correspondence and requests for materials should be addressed to L.Y. (email: yangboshi@live.cn) 


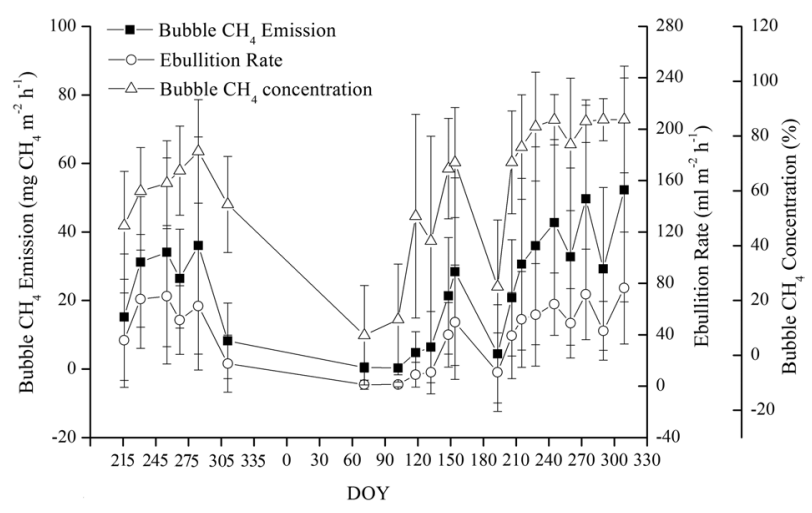

Figure 1. Mean ebullition rates, bubble $\mathrm{CH}_{4}$ emissions flux, and $\mathrm{CH}_{4}$ concentrations recorded from the inflow river. DOY: day of year, from 3 August 2016. Bars are $\pm S E, n=3$.

emissions were greater in summer than in other seasons at the Three Gorges Reservoir and were regulated by temperature, DO, and water velocity ${ }^{2}$, whereas they were only regulated by temperature at three lakes (Följesjön, Erssjön, and Skottenesjön) in southwest Sweden ${ }^{20}$. Analysis of these differences in effects of environmental factors on spatiotemporal variability in $\mathrm{CH}_{4}$ emissions from reservoirs may result in more accurate estimates of the total $\mathrm{CH}_{4}$ emissions than previously determined.

Emissions occur from rivers downstream of reservoirs, due to degassing fluxes at turbines and spillways. A large quantity of $\mathrm{CH}_{4}$ emits in the downstream river when the hypolimnion water passes through turbines and spillways because of the differences in temperature and pressure. The rapid stream of water increases the water current velocity, which enhances the gas transfer velocity at the air-water interface and improves downstream $\mathrm{CH}_{4}$ emission flux ${ }^{22} .50 \%$ of the total $\mathrm{CH}_{4}$ emissions recorded downstream from the Balbina Reservoir in Brazil ${ }^{18}$ represented approximately $30 \%$ of the total greenhouse gas emissions from the eight reservoirs in the dry tropical biome region of the country ${ }^{23}$, whereas downstream emissions accounted for $10 \%$ of the total $\mathrm{CH}_{4}$ emissions from the Nam Theun 2 Reservoir in $\mathrm{Laos}^{24}$.

In this study, we compared $\mathrm{CH}_{4}$ emissions from a reservoir with sites upstream and downstream to quantify spatial variations in $\mathrm{CH}_{4}$ emissions to ensure a more accurate estimation of $\mathrm{CH}_{4}$ emissions from hydroelectric reservoir systems. Specifically, we tested the hypothesis that upstream and downstream $\mathrm{CH}_{4}$ emissions are greater than from a reservoir.

\section{Results}

Temporal variation in ebullitive $\mathrm{CH}_{4}$ emissions. There were similar seasonal patterns of ebullition rate, bubble $\mathrm{CH}_{4}$ emission flux, and bubble $\mathrm{CH}_{4}$ concentration, all of which were lower in spring than in summer and autumn (Fig. 1). Mean ebullition rate from the upstream river was $39.93 \pm 24.3 \mathrm{ml} \mathrm{m}^{-2} \mathrm{~h}^{-1}$ (range: $1.17-$ $76.4 \mathrm{ml} \mathrm{m}^{-2} \mathrm{~h}^{-1}$ ), mean bubble $\mathrm{CH}_{4}$ flux rate was $22.62 \pm 15.1 \mathrm{mg} \mathrm{CH}_{4} \mathrm{~m}^{-2} \mathrm{~h}^{-1}$ (range: $0.31-52.27 \mathrm{mg} \mathrm{CH}_{4} \mathrm{~m}^{-2}$ $\mathrm{h}^{-1}$ ), and mean $\mathrm{CH}_{4}$ concentration by volume in the collected gas was $59.04 \pm 23.3 \%$ (range: $7.32-86.03 \%$ ). Ebullitive $\mathrm{CH}_{4}$ flux positively correlated with the ebullition rate $\left(R^{2}=0.92, P<0.001\right)$ and bubble $\mathrm{CH}_{4}$ concentration $\left(R^{2}=0.76, P<0.001\right.$, see Supplementary Fig. S3).

Temporal variation in diffusive $\mathrm{CH}_{4}$ emissions. $\mathrm{CH}_{4}$ emissions from the upstream river (NW) were low from February to June, but increased and fluctuated from July to January (Fig. 2). Furthermore, on a monthly scale, mean diffusive $\mathrm{CH}_{4}$ fluxes during the sampling period were similar and generally constant over time among the three areas of the main reservoir; however, fluxes peaked in the southwest (SW) lake on 1 August (DOY: 213) and 8 February (DOY: 39; Fig. 2). On a seasonal scale, there were similar seasonal patterns in $\mathrm{CH}_{4}$ fluxes among the three areas of the reservoir, where they were lowest in the spring and highest in the autumn (see Supplementary Fig. S4). Mean $\mathrm{CH}_{4}$ fluxes on the northeast (NE), SW, and southeast (SE) lakes in the next half year were $1.72,1.54,1.57$ times as many as those in the first half of year, respectively. In addition, there was some temporal variation in mean $\mathrm{CH}_{4}$ emissions downstream of the reservoir (DR), where it was highest in December 2014 and lowest in February 2015; otherwise, emissions were generally constant (Fig. 2).

Spatial variation in $\mathrm{CH}_{4}$ emissions. Mean flux in $\mathrm{CH}_{4}$ emissions from the upstream river was $3.65 \pm 3.24 \mathrm{mg} \mathrm{CH}_{4} \mathrm{~m}^{-2} \mathrm{~h}^{-1}$, whereas mean bubble $\mathrm{CH}_{4}$ flux (NW-B) was $2.73 \pm 2.02 \mathrm{mg} \mathrm{CH}_{4} \mathrm{~m}^{-2} \mathrm{~h}^{-1}$ and diffusive $\mathrm{CH}_{4}$ flux (NW-D) was $0.92 \pm 1.22 \mathrm{mg} \mathrm{CH}_{4} \mathrm{~m}^{-2} \mathrm{~h}^{-1}$ (Fig. 3). Although there were no bubble $\mathrm{CH}_{4}$ emissions in the reservoir or the downstream river, the mean diffusive $\mathrm{CH}_{4}$ emission flux in the reservoir was $0.082 \pm 0.061 \mathrm{mg}$ $\mathrm{CH}_{4} \mathrm{~m}^{-2} \mathrm{~h}^{-1}$ (NE: $0.076 \pm 0.049 \mathrm{mg} \mathrm{CH}_{4} \mathrm{~m}^{-2} \mathrm{~h}^{-1}$, SW: $0.106 \pm 0.083 \mathrm{mg} \mathrm{CH}_{4} \mathrm{~m}^{-2} \mathrm{~h}^{-1}$, and SE: $0.064 \pm 0.034 \mathrm{mg}$ $\mathrm{CH}_{4} \mathrm{~m}^{-2} \mathrm{~h}^{-1}$ ), which was lower than in the downstream river, where it was $0.49 \pm 0.20 \mathrm{mg} \mathrm{m}^{-2} \mathrm{~h}^{-1}$ (Fig. 3). Mean diffusive $\mathrm{CH}_{4}$ emissions from the upstream and downstream rivers were higher than those from the reservoir by a factor of 11 and 6, respectively (Fig. 3).

There was no significant difference in mean $\mathrm{CH}_{4}$ emissions from the marginal to pelagic zones among the three sampling areas of the reservoir (see Supplementary Fig. S5C-E); however, the mean $\mathrm{CH}_{4}$ emissions from the nearest sampling-point in the downstream river (DRP1: $0.78 \pm 0.44 \mathrm{mg} \mathrm{CH}_{4} \mathrm{~m}^{-2} \mathrm{~h}^{-1}$ ) were significantly 


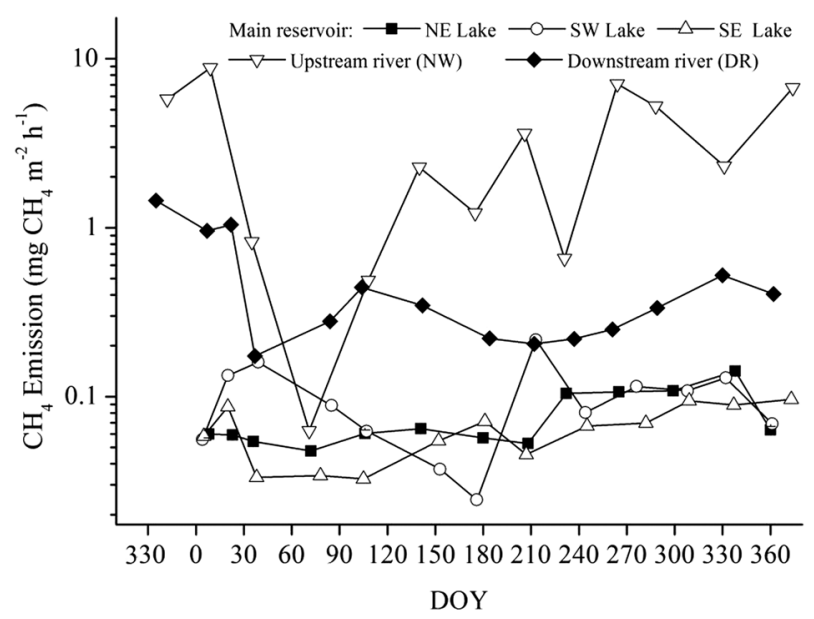

Figure 2. Seasonal dynamics in the average diffusive $\mathrm{CH}_{4}$ emissions, measured using floating chambers, from the different regions of Xin'anjiang Reservoir.

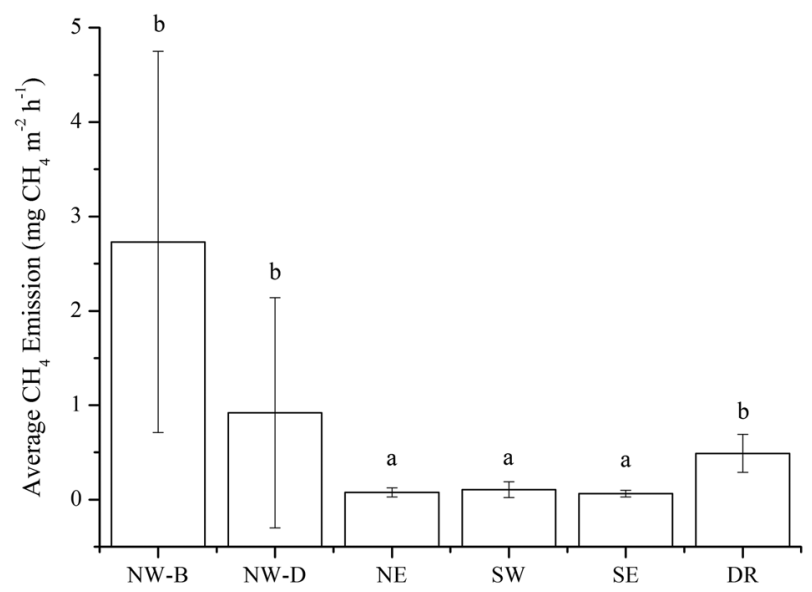

Figure 3. Mean $\mathrm{CH}_{4}$ emissions from the reservoir and the upstream and downstream rivers. NW-B, bubble emissions from the northwest transect (upstream); NW-D: diffusive emissions from the northwest transect. NE, northeast lake; SW, southwest lake; SE, southeast lake; DR, downstream river. Different small letters indicate the differences in mean $\mathrm{CH}_{4}$ emissions flux among the sampling areas at $P=0.05$.

higher than those from the second nearest sampling-point (DRP2: $0.34 \pm 0.30 \mathrm{mg} \mathrm{CH}_{4} \mathrm{~m}^{-2} \mathrm{~h}^{-1} ; P<0.001$; see Supplementary Fig. S5A), and the average $\mathrm{CH}_{4}$ emissions from the pelagic zones of the upstream river were significantly higher than those from the marginal zone (see Supplementary Fig. S5B).

Effects of temperature and wind speed on $\mathrm{CH}_{4}$ emissions. $\mathrm{CH}_{4}$ flux from the reservoir was positively correlated with wind speed and air-water temperature difference, whereas $\mathrm{CH}_{4}$ flux from the downstream river was positively correlated with air-water temperature difference (see Supplementary Tables S1 and S2).

\section{Discussion}

Comparison of $\mathrm{CH}_{4}$ emissions with other reservoirs. Average $\mathrm{CH}_{4}$ emissions from the main reservoir $\left(0.082 \pm 0.061 \mathrm{mg} \mathrm{CH}_{4} \mathrm{~m}^{-2} \mathrm{~h}^{-1}\right)$ are lower than those from the other temperate and subtropical reservoirs listed in Table 1, except for Douglas Lake, which is presumably due to the deep, oxic conditions and clean water quality in Xin'anjiang Reservoir ${ }^{25,26}$. The mean $\mathrm{CH}_{4}$ emissions from the upstream river in the study are comparable to that from Three Gorges Reservoir $\left(2.72 \mathrm{mg} \mathrm{CH}_{4} \mathrm{~m}^{-2} \mathrm{~h}^{-1}\right)$, which is one order of magnitude greater than that from Eguzon Reservoir $\left(0.24 \mathrm{mg} \mathrm{CH}_{4} \mathrm{~m}^{-2} \mathrm{~h}^{-1}\right)$, but significantly lower than those from Australian reservoirs and an agriculturally impacted reservoir in the United States, due to the differences in bubble activity (Table 1). The heterogeneity, specifically, differences in ebullition frequency and ebullition magnitudes, contribute to the variability in average $\mathrm{CH}_{4}$ fluxes observed among the reservoirs ${ }^{12}$. Frequency of bubble occurrence upstream of the reservoir is low (16.2\%), and the average ebullitive $\mathrm{CH}_{4}$ emission level is $16.83 \mathrm{mg} \mathrm{CH}_{4} \mathrm{~m}^{-2} \mathrm{~h}^{-1}$ (Table S4), which is one order of magnitude lower than the ebullition magnitudes in William H. Harsha Lake $\left(130.7 \mathrm{mg} \mathrm{CH}_{4} \mathrm{~m}^{-2} \mathrm{~h}^{-1}\right)$, Gold Creek (172.4 $\mathrm{mg} \mathrm{CH}_{4} \mathrm{~m}^{-2} \mathrm{~h}^{-1}$ ), and Little Nerang Dam (165.7 $\mathrm{mg} \mathrm{CH}_{4} \mathrm{~m}^{-2} \mathrm{~h}^{-1}$; Table 1). A large number of bubbles contribute to the extremely high $\mathrm{CH}_{4}$ emissions from the inflow rivers in the three reservoirs ${ }^{15,27-29}$. 


\begin{tabular}{|c|c|c|c|c|c|}
\hline \multirow[b]{2}{*}{ Country } & \multirow[b]{2}{*}{ Reservoir } & \multicolumn{3}{|c|}{$\mathrm{CH}_{4}$ Flux $\left(\mathrm{mg} \mathrm{CH}_{4} \mathrm{~m}^{-2} \mathrm{~h}^{-1}\right)$} & \multirow[b]{2}{*}{ Refs } \\
\hline & & Upstream river* & Open water area & Downstream river & \\
\hline \multirow{5}{*}{ China } & Xin’anjiang & $\begin{array}{l}2.73 \pm 2.02(\mathrm{~B}) \\
0.92 \pm 1.22(\mathrm{D})\end{array}$ & $0.082 \pm 0.061$ & $0.49 \pm 0.20$ & This study \\
\hline & Three Gorges & $2.72 \pm 1.98$ & $0.23 \pm 0.40$ & $0.26 \pm 0.16$ & 2,3 \\
\hline & Ertan & & $0.12 \pm 0.063$ & & 4 \\
\hline & Miyun & & $0.30 \pm 0.31$ & & 5 \\
\hline & 16 reservoirs in Chongqing & & $0.63 \pm 0.89$ & & 50 \\
\hline \multirow{4}{*}{ USA } & William H. Harsha Lake & $130.72 \pm 27.50$ & $9.77 \pm 2.00$ & & 27 \\
\hline & Douglas Lake & $0.018(\mathrm{D})$ & $0.017 \pm 0.012$ & & 51 \\
\hline & Eagle Creek & & $0.44 \pm 0.73$ & & 52 \\
\hline & 6 reservoirs in Western US & & $0.13-0.40$ & & 53 \\
\hline \multirow{2}{*}{ Australia } & Gold Creek & $172.36 \pm 24.72$ & $12.35 \pm 6.36$ & & 28 \\
\hline & Little Nerang Dam & $165.70 \pm 236.43$ & $7.70 \pm 19.38$ & & 29 \\
\hline \multirow{3}{*}{ Laos } & Nam Leuk & & $1.68 \pm 2.68$ & & 54 \\
\hline & Nam Ngum & & $0.13 \pm 0.13$ & & 54 \\
\hline & Nam Theun 2 & & $1.0-2.67$ & $\begin{array}{l}\text { Below the powerhouse: } 8.0 \pm 14.7 \\
\text { Below the Nakai Dam: } 0.93-2.2\end{array}$ & 24,33 \\
\hline France & Eguzon & $\begin{array}{l}0.24 \pm 0.56(\mathrm{~B}) \\
2.2 \pm 3.2(\mathrm{D})\end{array}$ & $0.4(0-2.67)$ & $0.68 \pm 0.68$ & 55 \\
\hline
\end{tabular}

Table 1. Literature review of $\mathrm{CH}_{4}$ emissions from temperate and subtropical reservoirs. ${ }^{*} \mathrm{CH}_{4}$ flux in upstream river: B: Bubble emission, D: Diffusive emission.

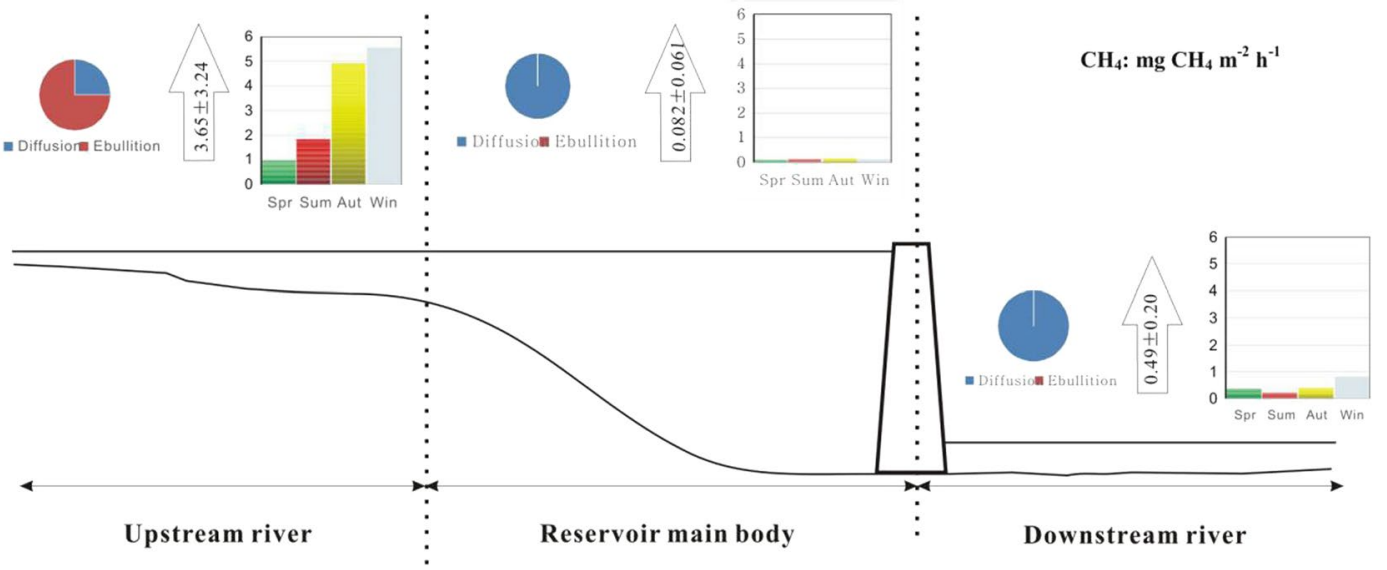

Figure 4. Schematic diagram of the spatiotemporal variability in $\mathrm{CH}_{4}$ emissions from Xin'anjiang Reservoir.

In regard to the downstream river of the reservoir, it has comparable $\mathrm{CH}_{4}$ emissions levels with the other listed reservoirs in Table 1.

Seasonal variation in $\mathrm{CH}_{4}$ emissions. In the upstream river, $\mathrm{CH}_{4}$ emissions in autumn and winter are higher than those in spring and summer (Fig. 4), due to the differences in the frequency of bubbles $(22.6 \%$ versus $8 \%$ ), but the differences do not reach a significant level $(\mathrm{p}>0.05)$ after performing a one-way ANOVA test. However, the results measured by the bubble traps indicate that the bubble $\mathrm{CH}_{4}$ emissions in summer and autumn are significantly higher than those in spring (Fig. 1). One of the major differences between the two methods is the duration of the measurement. The measurements using bubble traps were performed over 20-33-h periods, whereas chamber measurements were conducted for 20-30 min only. The floating chambers captured both ebullition and diffusive gas emissions ${ }^{27}$, whereas only $\mathrm{CH}_{4}$ ebullition fluxes were collected using bubble traps $^{8}$. However, the average ebullitive $\mathrm{CH}_{4}$ flux $\left(22.62 \pm 15.1 \mathrm{mg} \mathrm{CH}_{4} \mathrm{~m}^{-2} \mathrm{~h}^{-1}\right)$ measured using bubble traps was approximately 5 times higher than that measured using floating chambers $\left(3.65 \pm 3.24 \mathrm{mg} \mathrm{CH}_{4} \mathrm{~m}^{-2} \mathrm{~h}^{-1}\right)$. These differences can be explained by the sudden release of bubbles on these rare occasions, which reveals strong spatiotemporal heterogeneities of the ebullition process because ebullition is highly sporadic and occurs during a very short period of time $e^{7}$. The measurements using floating chambers are conducted over a short period of time and a small surface might lead to an underestimation of this emission pathway if hot spots and hot moments are missed during the deployment of the chambers. Such a phenomenon is strongly smoothed when using bubble traps over longer periods of time than the typical floating chamber deployment time (20-33 h versus 20-30 min $)^{30}$. 
Another explanation for the differences in $\mathrm{CH}_{4}$ emissions from the upstream river is that they were measured in different years (2014-2015 versus 2016-2017). Admittedly, interannual variability in upstream $\mathrm{CH}_{4} \mathrm{emis}^{-}$ sions presumably caused unnecessary errors. However, if the average $\mathrm{CH}_{4}$ flux is calculated only from these bubble-captured chambers in the NW transect in 2014 and 2015, it is $16.83 \pm 12.48 \mathrm{mg} \mathrm{CH}_{4} \mathrm{~m}^{-2} \mathrm{~h}^{-1}$, which is approximately $25 \%$ less than that measured by the bubble traps $\left(22.62 \pm 15.1 \mathrm{mg} \mathrm{CH}_{4} \mathrm{~m}^{-2} \mathrm{~h}^{-1}\right)$ in 2016 and 2017. Although both the interannual variability and different methods contributed to variances, differences remained in $\mathrm{CH}_{4}$ emissions when the diffusive and ebullitive $\mathrm{CH}_{4}$ fluxes were synchronously measured due to episodic bubbles. Nevertheless, the partitioning of bubble and diffusive $\mathrm{CH}_{4}$ emissions is an uncertainty in this study.

We observed that mean $\mathrm{CH}_{4}$ emissions from the reservoir in the second half of the year were higher than in the first half of the year (Fig. 2); this was due, in part, to seasonal hydrological dynamics. Hydrology mediates many biogeochemical processes, such as $\mathrm{O}_{2}$ concentration and thermal stratification, in aquatic systems. Zhang et al. (2015) found that oxycline and thermocline progressively sank in Xin'anjiang Reservoir in the second half of the year ${ }^{25}$. Vertical transport of $\mathrm{CH}_{4}$ in the water column is typically limited by slow rates of diffusion through the thermocline or oxycline ${ }^{31}$, and thermal and DO stratification typically become weaker in the second half of year, presumably resulting in increases in $\mathrm{CH}_{4}$ flux at the air-water interface.

Xin'anjiang Reservoir is a thermal stratification lake characterised by a short mixing period in February and March ${ }^{25}$. However, the vertical distributions of $\mathrm{CH}_{4}$ and $\mathrm{O}_{2}$ concentrations, and temperature were not measured in this study, which failed to illuminate the temporal variability in $\mathrm{CH}_{4}$ emissions. Lake overturn is a hot moment that exhibits disproportionately high $\mathrm{CH}_{4}$ emissions and $\mathrm{CH}_{4}$ oxidation ${ }^{32}$. Many studies indicate that $\mathrm{CH}_{4}$ storage sharply decreases during seasonal overturn periods ${ }^{32-35}$, emitting $12-46 \%$ of the total $\mathrm{CH}_{4}$ to the atmosphere, whereas the remainder (54-88\%) is consumed by methane-oxidizing bacteria ${ }^{32,34,35}$. Although a minor proportion of the storage $\mathrm{CH}_{4}$ was emitted to the atmosphere, the contribution to the annual diffusive $\mathrm{CH}_{4}$ emissions was still great ${ }^{32,34,35}$, and even extremely diffusive $\mathrm{CH}_{4}$ fluxes occurred ${ }^{33}$. However, $\mathrm{CH}_{4}$ emissions from the main reservoir did not show a pulse in February and May (Fig. 2), presumably because the low measurement frequency in our study did not capture the $\mathrm{CH}_{4}$ emission peaks. Thermal stratification and its impact on $\mathrm{CH}_{4}$ emissions is important to understanding the mechanisms of the spatial and temporal variability of $\mathrm{CH}_{4}$ emissions from reservoirs, which should be examined in the near future.

We recorded a clear peak in $\mathrm{CH}_{4}$ emissions $\left(0.25 \pm 0.15 \mathrm{mg} \mathrm{CH}_{4} \mathrm{~m}^{-2} \mathrm{~h}^{-1}\right)$ on 1 August (DOY: 213$)$ in the SW lake (Fig. 2), which was presumably due to the fluxes from the two marginal sampling points (SWP1 and SWP2) of $0.47 \pm 0.11 \mathrm{mg} \mathrm{CH}_{4} \mathrm{~m}^{-2} \mathrm{~h}^{-1}$ and $0.33 \pm 0.061 \mathrm{mg} \mathrm{CH}_{4} \mathrm{~m}^{-2} \mathrm{~h}^{-1}$, respectively (see Supplementary Table S7). The high $\mathrm{CH}_{4}$ fluxes from the marginal zone may be attributed to the decomposition of vegetation in the littoral zone when the water level increased to its highest point $(104.4 \mathrm{~m})$ in July (see Supplementary Fig. S2). It is likely that the gentle slopes that had adequate levels of soil on the banks of the SW transect permitted the growth of vegetation in the littoral zone during the spring when water levels were low, whereas the banks of the NE and SE lakes were steep and rocky and presumably less well vegetated. Similar peaks in $\mathrm{CH}_{4}$ emissions have also been reported from littoral zones of the Miyun and Three Gorges Reservoirs ${ }^{5,36}$.

We recorded another peak, albeit low $\left(0.16 \pm 0.097 \mathrm{mg} \mathrm{CH}_{4} \mathrm{~m}^{-2} \mathrm{~h}^{-1}\right)$ on 8 February (DOY: 39) in the SW lake (Fig. 2), which was caused by strong winds. Gas samples were only collected from three of the five sampling points due to unstable safety conditions on the surface of the reservoir. Mean $\mathrm{CH}_{4}$ fluxes were 0.23 and $0.20 \mathrm{mg} \mathrm{CH}_{4} \mathrm{~m}^{-2}$ $\mathrm{h}^{-1}$ at SWD2 and SWD4 (see Materials and Methods), respectively, when the wind speed reached 8-10 $\mathrm{m} \mathrm{s}^{-1}$, whereas the lowest $\mathrm{CH}_{4}$ flux at SWD5 $\left(0.049 \mathrm{mg} \mathrm{CH}_{4} \mathrm{~m}^{-2} \mathrm{~h}^{-1}\right)$ occurred in the central area of the reservoir due to the low wind speed $\left(2.63 \mathrm{~m} \mathrm{~s}^{-1}\right)$. Many studies support the opinion that $\mathrm{CH}_{4}$ emissions from water surfaces can be enhanced by strong wind speeds ${ }^{15,22,33,37}$.

Downstream $\mathrm{CH}_{4}$ emissions (including degassing at the turbines) have been found to be proportional to streamflow ${ }^{19}$. It is impossible to calculate the degassing emissions from the turbines at Xing'anjiang Dam based on the differences in $\mathrm{CH}_{4}$ concentrations between the water intake and water outlet below the dam because access is forbidden $500 \mathrm{~m}$ upstream and downstream of the dam due to safety concerns. However, measurements of $\mathrm{CH}_{4}$ emissions at four distances downstream of the dam, taken 13 times in 2015 (see Supplemental Table S9), were found to be at their lowest $\left(0.17 \pm 0.11 \mathrm{mg} \mathrm{CH}_{4} \mathrm{~m}^{-2} \mathrm{~h}^{-1}\right)$ in February, which is presumably a result of a low discharge flow rate $\left(275 \mathrm{~m}^{3} \mathrm{~s}^{-1}\right)$. Another possible explanation for the low flux is related to the lake overturn phenomenon in February ${ }^{25}$. Most of the $\mathrm{CH}_{4}$ stored in the hypolimnion is oxidized or released to the atmosphere during overturn periods ${ }^{32-35}$, and a very small fraction of the original quantity of $\mathrm{CH}_{4}$ remains in the water col$\mathrm{umn}^{32}$; thus, a low $\mathrm{CH}_{4}$ flux level was measured in the downstream river in February (Fig. 2).

Spatial variation in $\mathrm{CH}_{4}$ emissions. Upstream $\mathrm{CH}_{4}$ emissions are hot spots because they exhibit disproportionately high ebullitive $\mathrm{CH}_{4}$ emissions relative to the surrounding matrix ${ }^{38}$. Upstream river $\mathrm{CH}_{4}$ emission dynamics are predominantly influenced by bubbles since the peaks in the $\mathrm{CH}_{4}$ emissions flux (Fig. 2) are driven by bubbles (see Supplementary Table S4). In contrast to other studies ${ }^{21,24}$, we found that bubbles occurred in the deep-water zone $(>10 \mathrm{~m})$ rather than in the shallow zone $(<5 \mathrm{~m})$, and we suggest that the high ebullitive $\mathrm{CH}_{4}$ emissions from deep water zones are related to heterogeneous sediment accumulation ${ }^{12,13}$ because little or no sediment accumulates along reservoir margins ${ }^{39}$.

The average $\mathrm{CH}_{4}$ emission rate at the upstream site (NW) was one to 2 orders of magnitude greater than the other sites (Figs 2 and 3), highlighting the importance of identifying ebullition hot spots to improve total emissions estimates ${ }^{27}$. The results supported our hypothesis that $\mathrm{CH}_{4}$ emissions are higher in rivers upstream and downstream of the reservoir than in the main reservoir (Fig. 3), where high $\mathrm{CH}_{4}$ emissions from the upstream river were mediated by bubbles (Figs 1 and 3, see Supplementary Table S4). The $\mathrm{CH}_{4}$ in the gas bubbles can escape oxidation during transport through the water column as $\mathrm{CH}_{4}$ moves faster through the water column by ebullition than by diffusion ${ }^{40}$. 


\begin{tabular}{|c|c|c|}
\hline location & observations & ref \\
\hline Three Gorges Reservoir, China & $\begin{array}{l}\text { Upstream, reservoir tail waters and tributary sites had higher } \mathrm{CH}_{4} \text { fluxes } \\
\text { than the mainstream of the reservoir. }\end{array}$ & 3 \\
\hline Lake Kariba, Zambia/Zimbabwe & $\begin{array}{l}\text { Higher fluxes in river deltas }\left(\sim 10^{3} \mathrm{mg} \mathrm{CH}_{4} \mathrm{~m}^{-2} \mathrm{~d}^{-1}\right) \text { than nonriver bay } \\
\left.\text { (less than } 100 \mathrm{mg} \mathrm{CH}_{4} \mathrm{~m}^{-2} \mathrm{~d}^{-1}\right) \text { due to the high ebullition frequency and } \\
\text { ebullition magnitudes. }\end{array}$ & 27 \\
\hline Little Nerang Dam, Lake Wivenhoe, Lake Baroon, Australia & $\mathrm{CH}_{4}$ saturation was higher in inflow zones than in the main body. & \begin{tabular}{|l|}
27 \\
\end{tabular} \\
\hline William H. Harsha Lake, USA & $\begin{array}{l}\text { Extreme high } \mathrm{CH}_{4} \text { emission (mean: } 3137 \pm 660 \mathrm{mg} \mathrm{CH}_{4} \mathrm{~m}^{-2} \mathrm{~d}^{-1} \text { ) at the } \\
\text { most upstream site; } 1 \text { to } 2 \text { order of magnitude greater than the other } \\
\text { sites. }\end{array}$ & 27 \\
\hline Glod Creek Reservoir, Australia & $\begin{array}{l}\text { Highest } \mathrm{CH}_{4} \text { water-air fluxes were found at the main water inflow areas } \\
\text { of the reservoir. }\end{array}$ & 28 \\
\hline Little Nerang Dam, Australia & $\begin{array}{l}1.8-7.0 \% \text { of the upstream surface area called "ebullition zone"; } \\
97 \% \text { of the total methane occurred in the ebullition zones. }\end{array}$ & 29 \\
\hline Chapéu D’Uvas, Curuá-Una, Furnas, Brazil & $\begin{array}{l}\text { Elevated } p \mathrm{CH}_{4} \text { and } \mathrm{CH}_{4} \text { concentrations in river inflow areas and } \\
\text { decreasing values toward the dam; River inflows are hot spots of } \\
\text { diffusive } \mathrm{C} \text { gas flux. }\end{array}$ & 37 \\
\hline
\end{tabular}

Table 2. Some examples of studies reporting high methane emissions from the upstream inflow areas of reservoir.

Fluxes in $\mathrm{CH}_{4}$ ebullition in inflow water systems are common in the other reservoirs (Table 2), which may be attributable to the fact that water slows down in these areas and sediments have higher chances for deposition ${ }^{14}$. Sediment accumulation rates are positively correlated to the areal organic carbon burial rates ${ }^{39}$, and rapid burial of fresh sediments and organic matter made upstream sites more carbon rich and prime for $\mathrm{CH}_{4}$ production by anaerobic metabolism compared to other parts of the reservoirs ${ }^{12,15,27,37}$, as $\mathrm{CH}_{4}$ production in reservoirs is strongly driven by organic carbon availability ${ }^{41}$. Thus, ebullitive $\mathrm{CH}_{4}$ emissions are often reported to be exponentially increased with corresponding sediment accumulation rates ${ }^{14,42}$. The upstream reaches of Xin'anjiang Reservoir directly receive the catchment and stream inflow of industrial and domestic pollution ${ }^{43}$, which presumably fostered high rates of sediment $\mathrm{CH}_{4}$ production in the upstream rivers of the reservoir, causing ebullition zones to subsequently appear ${ }^{27,29}$. Moreover, ebullition rates tend to be highest in shallow areas because short water residence times limit the dissolution of $\mathrm{CH}_{4}$-rich bubbles released from the sediment ${ }^{44}$. The upstream river is the shallowest area compared with other regions (see Supplementary Table S3), which is beneficial for bubbles transport from the sediment to the atmosphere because of the small proportion of dissolved gas bubbles during ascent ${ }^{15,27,37}$. Additionally, $\mathrm{CH}_{4}$ imported from the Xin'anjiang catchment may further contribute to the observed pattern at river inflow areas.

We recorded higher $\mathrm{CH}_{4}$ emissions from the downstream river than from the surface of the reservoir adjacent to the dam (Fig. 2) that had presumably been released from dissolved $\mathrm{CH}_{4}$ in the hypolimnion layer of the reservoir ${ }^{17}$ because water inlets of turbines located in the hypolimnion layer $(26-37 \mathrm{~m} \text { under water surface })^{43}$ and the discharged water derived from the hypolimnion layer almost year round (except February, due to mixing periods). The water adjacent to the dam is thermally stratified, where water in the warmer, upper layer (epilimnion $<33 \mathrm{~m}$ ) is in contact with the atmosphere and is more oxygen-rich, whereas the deeper, colder layer (hypolimnion) contains relatively low levels of $\mathrm{O}_{2}$ concentration ${ }^{25}$. We suggest that $\mathrm{CH}_{4}$ produced in the reservoir is easily stored in the hypolimnion ${ }^{45}$, and the release of dissolved $\mathrm{CH}_{4}$ to the atmosphere occurs due to differences in pressure, temperature, and turbulence when water passes through the turbines and spillways ${ }^{19}$. Water passing through the turbines and spillways is drawn from the hypolimnion, and downstream $\mathrm{CH}_{4}$ emissions are released under decreased pressure below the dam ${ }^{19}$.

The explanation for the low $\mathrm{CH}_{4}$ emissions from the main reservoir is that the deep, oxic waterbody slows emissions by offering more options for $\mathrm{CH}_{4}$ oxidation. Water depths of the sampling points range from 10-69 $\mathrm{m}$, except for those on the margin (Table S3), and it is possible that such reservoir depths increase the possibility of oxidization for diffusive $\mathrm{CH}_{4}$ molecules. Moreover, Zhang et al. (2015) reported that the DO concentration never fell below $2 \mathrm{mg} / \mathrm{L}$, the critical value for anoxia, in Xin'anjiang Reservoir ${ }^{25}$. The lack of an anoxic layer permits the oxidization of dissolved $\mathrm{CH}_{4}$ under aerobic conditions by methanotrophic bacteria ${ }^{27}$. Furthermore, biomass clearing before flooding limited the availability of organic carbon ${ }^{26,43}$, which is important for $\mathrm{CH}_{4}$ production in sediments ${ }^{41}$. Chlorophyll a is a significant predictor of $\mathrm{CH}_{4}$ emissions from reservoir water surfaces ${ }^{1,37}$, and Xin'anjiang Reservoir is presently in an oligotrophic state, with a low concentration of chlorophyll a $\left(1-3 \mu \mathrm{gL}^{-1}\right)^{26}$, which limits $\mathrm{CH}_{4}$ emissions from the reservoir. Moreover, the dendritic shape of Xin'anjiang Reservoir facilitates the deposition of allochthonous organic carbon in the sediment of the NW lake (see Supplementary Fig. S1) ${ }^{46}$, and limited fresh sediments are deposited in the main reservoir.

Mitigation strategies for $\mathrm{CH}_{4}$ emissions. Management strategies should increase $\mathrm{CH}_{4}$ oxidation in the sediments and water columns and decrease $\mathrm{CH}_{4}$ production, ebullition, and degassing emission at the dam to mitigate $\mathrm{CH}_{4}$ emissions from reservoirs. Extremely allochthonous organic material and organic carbon burial stimulated ebullition in the upstream rivers and river deltas ${ }^{12,14}$; therefore, periodical dredge campaigns ${ }^{27}$, reducing watershed soil erosion ${ }^{14}$ and nutrient input ${ }^{47}$, can efficiently reduce ebullitive $\mathrm{CH}_{4}$ emissions. Moreover, the location of spillways and turbines have an impact on $\mathrm{CH}_{4}$ emissions from reservoirs ${ }^{27}$.

Previous studies have shown that extreme $\mathrm{CH}_{4}$ ebullitive emissions are ultimately attributable to very high sedimentation rates ${ }^{14}$, as well as exhibiting an exponentially increasing relationship between $\mathrm{CH}_{4}$ ebullitive 
emissions and the sediment accumulated rates in the 6 small reservoirs of the Saar River ${ }^{42}$. The mechanism is characterised by deeper sediment layers contributing to $\mathrm{CH}_{4}$ formation ${ }^{42}$, and the deeply accumulated $\mathrm{CH}_{4}$ causes supersaturation and consequent bubble formation and release ${ }^{14}$. In the study, inflow rivers are ebullition hot spots, thus policymakers should take effective measures to control substantial $\mathrm{CH}_{4}$ emissions. The sediment is dredged periodically to reduce deposited organic matter, which presumably decreases the magnitude of ebullitive $\mathrm{CH}_{4}$ emissions efficiently, although carbon leakage occurs during the process ${ }^{27}$.

Another practical measure is to prevent the excessive input of nutrients and pollution to the reservoir ${ }^{30,47,48}$, which would reduce the available organic carbon for $\mathrm{CH}_{4}$ production ${ }^{47}$. Cage culture is an important nutrient input, which enhances $\mathrm{N}, \mathrm{P}$, and TOC accumulation in the sediments of the lacustrine zone ${ }^{48}$. Moreover, the NW lake received more soil erosion, sewage input, and industrial pollution from the upstream rivers in Anhui Province. In response, authorities have taken measures to decrease the inputs of all types of pollution, such as cage culture prohibition and inter-provincial ecological compensation, which improved the water quality in the upstream river from a eutrophic to mesotrophic state, presumably decreasing $\mathrm{CH}_{4}$ production and emissions from the reservoir ${ }^{37}$.

Dam design is also important for $\mathrm{CH}_{4}$ emissions, especially the location of water intakes. $\mathrm{CH}_{4}$ concentrations are higher in the hypolimnion than in the epilimnion during thermal stratification periods ${ }^{19}$. The degassing that occurs as hypolimnion water is routed through a dam accounts for a large fraction $(>50 \%)$ of the total $\mathrm{CH}_{4}$ emissions in some Amazon tropical reservoirs ${ }^{17,18}$. However, if turbine intakes are located in the upper layer of a dam, shallow waters will be withdrawn during thermal stratification to avoid substantial $\mathrm{CH}_{4}$ degassing from the $\mathrm{CH}_{4}$-rich water in the hypolimnion ${ }^{19}$, for example, only $0.8 \%$ from Harsha Lake ${ }^{27}$. Moreover, a significant increase in $\mathrm{CH}_{4}$ emissions was reported $3 \mathrm{~km}$ upstream from Nam Theum 2 Dam due to the artificial mixing induced by water intakes ${ }^{33}$, and $\mathrm{CH}_{4}$-rich water from the reservoir's hypolimnion reached the surface and resulted in a high $\mathrm{CH}_{4}$ diffusive flux. Therefore, the water intake in the hypolimnion not only increased the degassing flux at the dam but also risked enhancing the $\mathrm{CH}_{4}$ diffusive flux upstream of the dam.

In summary, upstream rivers are hot spots in bubble $\mathrm{CH}_{4}$ emissions, significantly contributing to the total $\mathrm{CH}_{4}$ emissions from hydroelectric reservoir systems. If upstream sites are ignored in field-sampling strategies, entire-system $\mathrm{CH}_{4}$ emissions will be underestimated. $\mathrm{CH}_{4}$ emissions from a main reservoir are lower than that from a downstream river. Capturing the spatial heterogeneity of $\mathrm{CH}_{4}$ emissions is vital to estimating the total $\mathrm{CH}_{4}$ emissions in a hydroelectric system. Seasonal variation in $\mathrm{CH}_{4}$ emissions exhibited a high value in autumn and winter and a low value in spring and summer. A thorough investigation should be conducted for the entire reservoir region over a long period because bubbles are episodic and diffusive $\mathrm{CH}_{4}$ emission flux exhibits a strong spatiotemporal variability.

\section{Materials and Methods}

Study sites. Xin'anjiang Reservoir $\left(118^{\circ} 42^{\prime}-118^{\circ} 59^{\prime} \mathrm{E}, 29^{\circ} 28^{\prime}-29^{\circ} 58^{\prime} \mathrm{N}\right)$ is located in China's north subtropical zone. The mean annual air temperature, precipitation, and evaporation are $17.7^{\circ} \mathrm{C}, 2015.1 \mathrm{~mm}$, and $712.9 \mathrm{~mm}$, respectively (see Supplementary Fig. S2). Constructed in 1959, the reservoir has a water surface area of $580 \mathrm{~km}^{2}$ and mean depth of $37 \mathrm{~m}$, with a capacity of approximately $1.78 \times 10^{10} \mathrm{~m}^{343}$, and an annual average inflow and outflow of $9.4 \times 10^{9} \mathrm{~m}^{3}$ and $9.1 \times 10^{9} \mathrm{~m}^{3}$, respectively. Water retention time is approximately 2 years, and in 2015 , the water level fluctuated between 98 and $104 \mathrm{~m}$ above elevation (see Supplementary Fig. S2). According to China's surface water classification standards, the water quality of Xin'anjiang Reservoir is grade I, serving as an important water source in eastern China that presently provides drinking water.

The reservoir consists of a series of connected lakes in all cardinal directions around a central lake that serves as the main waterbody (see Supplementary Fig. S1). The watercourse of the northwest lake is the dominant source of upstream inflow, contributing $60-80 \%$ of the total inflow. The downstream river is the watercourse below Xinanjiang Dam.

The four sub-lakes and downstream river were sampled at points along transects (see Supplementary Fig. S1). The NW lake transect $\left(118^{\circ} 43^{\prime} 04^{\prime \prime} \mathrm{E}, 29^{\circ} 44^{\prime} 03^{\prime \prime} \mathrm{N}\right)$, located in the main upstream inflow inlet, has a width of $0.3 \mathrm{~km}$ and three sampling points extending 10, 50, and $120 \mathrm{~m}$ (NWP1, NWP2, and NWP3, respectively) from the southern bank marginal zone to the pelagic zone, whereas the NE $\left(119^{\circ} 03^{\prime} 03^{\prime \prime} \mathrm{E}, 29^{\circ} 38^{\prime} 44^{\prime \prime} \mathrm{N}\right)$, SW $\left(118^{\circ} 44^{\prime} 39^{\prime \prime} \mathrm{E}\right.$, $\left.29^{\circ} 28^{\prime} 18^{\prime \prime} \mathrm{N}\right)$, and SE $\left(118^{\circ} 45^{\prime} 20^{\prime \prime} \mathrm{E}, 29^{\circ} 28^{\prime} 39^{\prime \prime} \mathrm{N}\right)$ lake transects are located in the open water and have five sampling points ( $\mathrm{P} 1$ to $\mathrm{P} 5$ ) extending from the marginal to pelagic zones (Table S3). Four sampling points in the downstream river below the dam are located $0.35,1,4$, and $7 \mathrm{~km}$ from Xin'anjiang Dam (DRP1, DRP2, DRP3, and DRP4, respectively).

$\mathrm{CH}_{4}$ flux measurement. Floating static chambers were used to collect gas samples at all sampling points between 08:30 and 11:30 hrs, monthly from December 2014 to December 2015, and bubble traps were used to collect bubbles from the upstream river from August 2016 to November 2017, where samples were collected once or twice per month, except November 2016, and January and February 2017. Air and water temperatures were measured using an alcohol thermometer, and wind speed in the field was measured using an anemometer (Kestrel 1000, Nielsen-Kellerman Co., USA).

Flux of diffusive $\mathrm{CH}_{4}$ emissions was collected using floating static chambers and analysed by gas chromatograph. Three floating static chambers (basal area of $0.29 \mathrm{~m}^{2}$ and volume of $0.117 \mathrm{~m}^{3}$ ) at each sampling point comprised a non-covered plastic box wrapped in light-reflecting and heatproof materials to minimize internal temperature variation, with plastic foam collars fixed to opposite sides. The headspace height inside the chamber was approximately $35 \mathrm{~cm}$. A silicone tube $(0.6$ and $0.4 \mathrm{~cm}$ outer and inner diameters, respectively) was inserted into the upper central side of the chamber to collect gas samples that were then dried to prevent biological reactions in plexiglass tubes filled with calcium chloride (anhydrous, analytical reagent). Another silicone tube was inserted into the upper corner of the chamber to maintain a balance in air pressure between the inside and outside 
of the chamber. Static chambers drifted freely behind a boat to reduce measurement bias ${ }^{49}$. Samples of gas were collected from the static chamber in air-sampling bags $(0.5 \mathrm{~L}$, Hedetech, Dalian, China) four times every 7 min over a 21-min period using a hand-driven pump (NMP830KNDC, KNF Group, Freiburg, Germany) and were stored until analysis ${ }^{2}$. The air-sampling bags made of aluminium are suitable for gas storage for 7 days and do not absorb or react with $\mathrm{CH}_{4}$. Leakage and memory effects of the air-sampling bags were tested in earlier experiments.

We placed 16-26 bubble traps 10-15 $\mathrm{m}$ apart in a river crossing rope in the upstream river, where water depth ranged from $5-25 \mathrm{~m}$. The traps consisted of an inverted $30-\mathrm{cm}$ diameter circular funnel fixed to the neck of a 0.56-L plastic bottle, and an additional skirt (50-cm diameter) was fixed to the funnel aperture to enlarge the area over which bubbles were collected ${ }^{8}$. Each funnel was stabilized with three equally sized weights to ensure no tiny bubbles remained in the traps at the initial stage. Trapped gas bubbles liberated from water were collected in the bottles after 24 hours, and then the remaining volume of water was measured to calculate the volume of liberated gas bubbles. The trapped gas was diluted 1000 times by injecting $1 \times 10^{-3}$ - L of trapped gas into 1 - or 0.5 -L gas bags that had been filled with $\mathrm{N}_{2}$ to facilitate analysis of $\mathrm{CH}_{4}$ concentration by gas chromatography. Trapped gas within these bags was analysed within 3 days using a gas chromatograph (Agilent 7890 A, Agilent Technologies, Santa Clara, USA) equipped with a flame ionization detector (FID). The oven, injector, and detector temperatures were set at 70,25 , and $200^{\circ} \mathrm{C}$, respectively. Standard mixed gas $\left(\mathrm{CH}_{4}: 1.83 \mathrm{ppm}\right.$, provided by the China National Research Centre for Certified Reference Materials, Beijing) was used to quantify the $\mathrm{CH}_{4}$ concentration in one of every 10 samples, and the coefficient of variation of $\mathrm{CH}_{4}$ concentration in the replicated samples was $<1 \%$.

The increasing rate of gas concentration $(d c / d t)$ within the static chamber was calculated as the slope of the linear regression of the gas concentration versus time. Diffusion chambers collect diffusive emissions as well as ebullitive emissions if they are present. Therefore, if the slope of the linear regression of the gas concentration in the chamber versus time was linear, with $\mathrm{R}^{2}>0.9$, then the chamber was assumed to collect only diffusive emissions. If $\mathrm{R}^{2}<0.9$, then the chamber was assumed to collect total (diffusive + ebullitive) emissions ${ }^{30}$.

The flux of diffusive $\mathrm{CH}_{4}$ emissions $\left(\mathrm{F}_{1}, \mathrm{mg} \mathrm{CH}_{4} \mathrm{~m}^{-2} \mathrm{~h}^{-1}\right)$ is calculated as (Eq. 1):

$$
F_{1}=\rho \times \frac{d c}{d t} \times \frac{273.15}{273.15+T} \times H
$$

where $\rho$ is the density of gas under the standard conditions $\left(0.714 \mathrm{~kg} \mathrm{~m}^{-3}\right.$ for $\left.\mathrm{CH}_{4}\right), \mathrm{H}$ is the height from the top of the inverted chamber to the water surface (here, $0.35 \mathrm{~m}$ ), 273.15 is the absolute temperature at $0{ }^{\circ} \mathrm{C}$, and $\mathrm{T}$ is the air temperate $\left({ }^{\circ} \mathrm{C}\right)$.

The flux of $\mathrm{CH}_{4}$ via ebullition $\left(F_{2}: \mathrm{mg} \mathrm{CH}_{4} \mathrm{~m}^{-2} \mathrm{~h}^{-1}\right)$, measured as the bubble $\mathrm{CH}_{4}$ flux by bubble traps, is calculated as (Eq. 2):

$$
F_{2}=\frac{C_{C H 4} \times V \times M}{A_{f} \times t \times V_{m}} \times \frac{1}{1000}
$$

where $C_{C H 4}$ is the $\mathrm{CH}_{4}$ concentration $\left(\mu \mathrm{L} \mathrm{L}^{-1}\right), V$ is the accumulated headspace gas volume $(\mathrm{L}), M$ is the molar weight of $\mathrm{CH}_{4}\left(16.04 \mathrm{~g} \mathrm{~mol}^{-1}\right), A_{f}$ is the funnel area $\left(0.14 \mathrm{~m}^{2}\right), t$ is the measurement duration (h), and $V_{m}$ is the molar volume of gas at room temperature $\left(22.4 \mathrm{~L} \mathrm{~mol}^{-1}\right)^{8}$.

The ebullition rate $\left(E R ; \mathrm{mL} \mathrm{m}^{-2} \mathrm{~h}^{-1}\right)$, which reflects the volume rate of released accumulated bubbles, is calculated as (Eq. 3).

$$
E R=\frac{V}{A_{f} \times t}
$$

where the parameters $V, A_{f}$, and $t$ are provided in Eq. (2).

Statistical analysis. The flux in $\mathrm{CH}_{4}$ emissions data that did not meet the test for normality (Kolmogorov-Smirnov) were transformed to trigonometric or logarithmic functions prior to testing for seasonal and spatial variability using one-way analysis of variance (ANOVA) and Tukey's HSD test. Data were analysed using the SPSS statistical package (v. 18.0, Chicago, IL, USA).

\section{References}

1. Deemer, B. et al. Greenhouse gas emissions from reservoir water surfaces: a new global synthesis. Bioscience 66, 949-964 (2016).

2. Yang, L. et al. Spatial and seasonal variability of diffusive methane emissions from the Three Gorges Reservoir. J. Geophys. Res. 118, 471-481 (2013)

3. Zhao, Y., Wu, B. \& Zeng, Y. Spatial and temporal patterns of greenhouse gas emissions from Three Gorges Reservoir of China. Biogeosciences 10, 1219-1230 (2013).

4. Zheng, H. et al. Spatial-temporal variations of methane emissions from the Ertan hydroelectric reservoir in southwest China. Hydrol. Process. 25, 1391-1396 (2011).

5. Yang, M. et al. Spatial and seasonal $\mathrm{CH}_{4}$ flux in the littoral zone of Miyun Reservoir near Beijing: the effects of water level and its fluctuation. Plos one 9, e94275 (2014).

6. Bastviken, D., Tranvik, L., Downing, J., Crill, P. \& Enrich-Prast, A. Freshwater methane emissions offset the continental carbon sink. Science 331, 50 (2011).

7. Maeck, A., Hofmann, H. \& Lorke, A. Pumping methane out of aquatic sediments-ebullition forcing mechanisms in an impounded river. Biogeosciences 11, 2925-2938 (2014).

8. Wik, M., Crill, P., Varner, R. \& Bastviken, D. Multiyear measurements of ebullitive methane flux from three subarctic lakes. J. Geophys. Res. 118, 1307-1321 (2013).

9. Tokida, T. et al. Falling atmospheric pressure as a trigger for methane ebullition from peatland. Global Biogeochem. Cy. 21, GB2003 (2007). 
10. Casper, P., Maberly, S. C., Hall, G. H. \& Finlay, B. J. Fluxes of methane and carbon dioxide from a small productive lake to the atmosphere. Biogeochemistry 49, 1-19 (2000).

11. DelSontro, T., McGinnis, D., Sobek, S., OStrovsky, I. \& Wehrli, B. Extreme methane emissions from a Swiss hydropower reservoir: contribution from bubbling sediments. Environ. Sci. Technol. 44, 2419-2425 (2010).

12. DelSontro, T. et al. Spatial heterogeneity of methane ebullition in a large tropical reservoir. Environ. Sci. Technol. 45, 9866-9873 (2011).

13. DelSontro, T., Boutet, L., St-Pierre, A., Del Giorgio, P. \& Prairie, Y. Methane ebullition and diffusion from northern ponds and lakes regulated by the interaction between temperature and system productivity. Limnol. Oceanogr. 61, S62-S77 (2016).

14. Sobek, S., DelSontro, T., Wangfun, N. \& Wehrli, B. Extreme organic carbon burial fuels intense methane bubbling in a temperate reservoir. Geophys. Res. Lett. 39, L01401 (2012).

15. Musenze, R. et al. Assessing the spatial and temporal variability of diffusive methane and nitrous oxide emissions from subtropical freshwater reservoirs. Environ. Sci. Technol. 48, 14499-14507 (2014).

16. Teodoru, C. R. et al. The net carbon footprint of a newly created boreal hydroelectric reservoir. Global Biogeochem. Cy. 26, GB2016 (2012).

17. Abril, G. et al. Carbon dioxide and methane emissions and the carbon budget of a 10-year old tropical reservoir (Petit Saut, French Guiana). Global Biogeochem. Cy. 19, (GB4007 (2005).

18. Kemenes, A., Forsberg, B. \& Melack, J. Methane release below a tropical hydroelectric dam. Geophys. Res. Lett. 34, L12809 (2007).

19. Fearnside, P. \& Pueyo, S. Greenhouse-gas emissions from tropical dams. Nat. Clim. Change 2, 382-384 (2012).

20. Natchimuthu, S. et al. Spatio-temporal variability of lake $\mathrm{CH}_{4}$ fluxes and its influence on annual whole lake emission estimates. Limnol. Oceanogr. 61, S13-S26 (2016).

21. Rodriguez, M. \& Casper, P. Greenhouse gas emissions from a semi-arid tropical reservoir in northeastern Brazil. Reg. Environ. Change 18, 1-12 (2018).

22. Beaulieu, J. J., Shuster, W. D. \& Rebholz, J. A. Controls on gas transfer velocities in a large river. J. Geophys. Res. 117, G02007 (2012).

23. Ometto, J. et al. Carbon emission as a function of energy generation in hydroelectric reservoirs in Brazilian dry tropical biome. Energ. Policy 58, 109-116 (2013).

24. Deshmukh, C. et al. Low methane $\left(\mathrm{CH}_{4}\right)$ emissions downstream of a monomictic subtropical hydroelectric reservoir (Nam Theun 2, Lao PDR). Biogeosciences 13, 1919-1932 (2016).

25. Zhang, Y. et al. Dissolved oxygen stratification and response to thermal structure and long-term climate change in a large and deep subtropical reservoir (Lake Qiandaohu, China). Water Res. 75, 249-258 (2015).

26. Wang, F. et al. Seasonal variation of $\mathrm{CO}_{2}$ diffusion flux from a subtropical reservoir in East China. Atmos. Environ. 103, 129-137 (2015).

27. Beaulieu, J., Smolenski, R., Nietch, C., Townsent-Small, A. \& Elovitz, M. High $\mathrm{CH}_{4}$ emissions from a midlatitude reservoir draining an agricultural watershed. Environ. Sci. Technol. 48, 11100-11108 (2014).

28. Sturm, K., Yuan, Z., Gibbes, B. \& Grinham, A. Methane and nitrous oxide sources and emissions in a subtropical freshwater reservoir, South East Queenland, Australia. Biogeosciences 11, 5245-5248 (2014).

29. Grinham, A., Dunbabin, M., Gale, D. \& Udy, J. Quantification of ebullitive and atmosphere from a water storage. Atmos. Environ. 45, 7166-7173 (2011).

30. Deshmukh, C. et al. Physical controls on $\mathrm{CH}_{4}$ emissions from a newly flooded subtropical freshwater hydroelectric reservoir: Nam Theun 2. Biogeosciences 11, 4251-4269 (2014).

31. Schubert, C. et al. Oxidation and emission of methane in a monomictic lake (Rotsee, Switzerland). Aquat. Sci. 72, 455-466 (2010).

32. Kankaala, P., Taipale, S., Nykänen, H. \& Jones, R. Oxidation, efflux, and isotopic fractionation of methane during autumnal turnover in a polyhumic, boreal lake. J. Geophys. Res. 112, G02003 (2007).

33. Guérin, F. et al. Effect of sporadic destratification, seasonal overturn, and artificial mixing on $\mathrm{CH}_{4}$ emissions from a subtropical hydroelectric reservoir. Biogeosciences 13, 3647-3663 (2016).

34. Schubert, C. J., Diem, T. \& Eugster, W. Methane emissions from a small wind shield lake determined by eddy covariance, flux chambers, anchored funnels, and boundary model calculations: a comparison. Environ. Sci. Technol. 46, 4515-4522 (2012).

35. Fernández, J., Peeters, F. \& Hofmann, H. Importance of autumn overturn and anoxic conditions in the hypolimnion for the annual methane emissions from a temperate lake. Environ. Sci. Technol. 48, 7297-7304 (2014).

36. Yang, L. et al. Surface methane emissions from different land use types during various water levels in three major drawdown areas of the Three Gorges Reservoir. J. Geophys. Res. 117, D10109 (2012).

37. Paranaíba, J. R. et al. Spatially resolved measurements of $\mathrm{CO}_{2}$ and $\mathrm{CH}_{4}$ concentration and gas-exchange velocity highly influence carbon-emission estimates of reservoirs. Environ. Sci. Technol. 52, 607-615 (2018).

38. McClain, M. E. et al. Biogeochemical hot spots and hot moments at the interface of terrestrial and aquatic ecosystems. Ecosystems 6 , 301-312 (2003).

39. Mendonça, R. et al. Carbon sequestration in a large hydroelectric reservoir: an integrative seismic approach. Ecosystems 17, 430-441 (2014).

40. Joyce, J. \& Jewell, P. W. Physical controls on methane ebullition from reservoirs and lakes. Environ. Eng. Geosci. 8(2), 167-178 (2003).

41. Venkiteswaran, J. J. et al. Processes affecting greenhouse gas production in experimental boreal reservoirs. Global Biogeochem. Cy. 27(2), 567-577 (2013).

42. Maeck, A. et al. Sediment trapping by dams creates methane emission hot spots. Environ. Sci. Technol. 47, 8130-8137 (2013).

43. Jin, X., Liu, S., Zhang, Z., Tu, Q. \& Xu, N. Environment of Chinese lake (ed. Jin, X.) 318-337 (Ocean Press, Beijing, China, 1995).

44. McGinnis, D. F., Greinert, J., Artemov, Y., Beaubien, S. E. \& Wüest, A. Fate of rising bubbles in stratified waters: How much methane reaches the atmosphere? J. Geophys. Res. 111, C09007 (2006).

45. Bastviken, D., Cole, J. \& Pace, M. Methane emissions from lakes: dependence of lake characteristics, two regional assessments, and a global estimate. Global Biogeochem. Cy. 18, GB4009 (2004).

46. Yu, Y. The Analysis of the deposits of the Xinanjiang Reservoir (in Chinese with English Abstract). J. East China Norm. Univ. (Nat. Sci.) 3, 77-84 (1998).

47. West, W. E., Coloso, J. J. \& Jones, S. Effects of algal and terrestrial carbon on methane production rates and methanogen community structure in a temperature lake sediment. Freshwater Biol. 57, 949-955 (2012).

48. Jia, X. et al. Historical record of nutrients inputs into the Xinan Reservoir and its potential environmental implication. Environ. Sci. Pollut. Res. 24(9), 1-12 (2017).

49. Lorke, A. et al. Technical note:drifting versus anchored flux chambers for measuring greenhouse gas emissions from running waters. Biogeosciences 12, 7013-7024 (2015).

50. Wang, X. et al. Greenhouse gases concentrations and fluxes from subtropical small reservoirs in relation with watershed urbanization. Atmos. Environ. 154, 225-235 (2017).

51. Mosher, J. et al. Spatial and temporal correlates of greenhouse gas diffusion from a hydropower reservoir in the southern United States. Water 7, 5910-5927 (2015)

52. Jacinthe, P., Filippelli, G., Tedesco, L. \& Raftis, R. Carbon storage and greenhouse gases emission from a fluvial reservoir in an agricultural landscape. Catena 94, 53-63 (2012).

53. Soumis, N., Duchemin, E., Canuel, R. \& Lucotte, M. Greenhouse gas emissions from reservoirs of the western United States. Global Biogeochem. Cy. 18, GB3022 (2004). 
54. Chanudet, V. et al. Gross $\mathrm{CO}_{2}$ and $\mathrm{CH}_{4}$ emissions from the Nam Ngum and Nam Leuk sub-tropical reservoirs in Lao PDR. Sci. Total Environ. 409, 5382-5391 (2011).

55. Descloux, S., Chanudet, V., Serça, V. \& Guérin, F. Methane and nitrous oxide annual emissions from an old eutrophic temperature reservoir. Sci. Total Environ. 598, 959-972 (2017).

\section{Acknowledgements}

The study was funded by the National Natural Science Foundation of China (41303065) and Zhejiang Hangzhou Urban Forest Ecosystem Research Station. We thank Li Hepeng and Yue Chunlei for financial support for the manuscript publication, the Xinanjiang hydropower plant for provision of streamflow data below the dam, Sun Binfeng for the photograph in Supplementary Fig. S1, Xu Gaofu for provision of meteorology data presented in Supplementary Fig. S2. Data presented in this work can be found in the supporting information.

\section{Author Contributions}

Y. L. designed the experiments, collected the data, and wrote the manuscript.

\section{Additional Information}

Supplementary information accompanies this paper at https://doi.org/10.1038/s41598-019-44470-2.

Competing Interests: The author declares no competing interests.

Publisher's note: Springer Nature remains neutral with regard to jurisdictional claims in published maps and institutional affiliations.

(c) (i) Open Access This article is licensed under a Creative Commons Attribution 4.0 International License, which permits use, sharing, adaptation, distribution and reproduction in any medium or format, as long as you give appropriate credit to the original author(s) and the source, provide a link to the Creative Commons license, and indicate if changes were made. The images or other third party material in this article are included in the article's Creative Commons license, unless indicated otherwise in a credit line to the material. If material is not included in the article's Creative Commons license and your intended use is not permitted by statutory regulation or exceeds the permitted use, you will need to obtain permission directly from the copyright holder. To view a copy of this license, visit http://creativecommons.org/licenses/by/4.0/.

(C) The Author(s) 2019 